\title{
Relation of subacute stent thrombosis and resistance to acetylsalicylic acid and clopidogrel in patients with acute coronary syndrome. Insights from the ANIN Myocardial Infarction Registry
}

Podostra zakrzepica w stencie a laboratoryjnie stwierdzona oporność na klopidogrel i kwas acetylosalicylowy u pacjentów z ostrym zespołem wieńcowym. Obserwacje z Rejestru Zawałów Serca ANIN

Jerzy Pręgowski¹, Jakub Przyłuski', Maciej Karcz¹, Bożena Norwa-Otto², Mariusz Kruk², Łukasz Kalińczuk², Paweł Tyczyński ${ }^{1}$, Michał Ciszewski ${ }^{1}$, Witold Rużyłło ${ }^{1}$, Dariusz Sitkiewicz ${ }^{3}$, Adam Witkowski ${ }^{1}$

${ }^{1}$ Department of Interventional Cardiology and Angiology, Institute of Cardiology, Warsaw, Poland

2Department of Coronary Artery Disease and Structural Heart Diseases, Institute of Cardiology, Warsaw, Poland

${ }^{3}$ Department of Biochemistry and Clinical Chemistry, Medical University of Warsaw, Poland

Post Kardiol Interw 2010; 6, 4 (22): 154-160 DOI: $10.5114 /$ pwki.2010.17628

\begin{abstract}
Background: Stent thrombosis (ST) is a catastrophic complication of percutaneous coronary interventions ( $\mathrm{PCI})$.

Aim: To assess the relation between subacute ST and response to antiplatelet treatment in patients with acute coronary syndrome (ACS) and to check the effect of doubling the maintenance dose of clopidogrel on platelet response.

Material and methods: We performed a retrospective search of the prospective single-centre ANIN Myocardial Infarction Registry and enrolled 22 patients with a history of subacute ST following PCI for ACS and 36 matched control subjects. Platelet aggregation was assessed at baseline under monotherapy with acetylsalicylic acid (ASA) 75 mg and after 7 days of dual therapy with ASA and clopidogrel $75 \mathrm{mg}$ daily. Platelet function was evaluated with light transmittance aggregometry after addition of an agonist: epinephrine $(30 \mu \mathrm{mol} / \mathrm{l})$ or adenosine $5^{\prime}$-diphosphate (ADP) $(5 \mu \mathrm{mol} / \mathrm{l})$. Patients in whom clopidogrel resistance was identified were administered a maintenance dose of $150 \mathrm{mg}$ and after 7 days platelet aggregation was assessed again.

Results: Maximal epinephrine-induced aggregation in patients on ASA who developed ST and in control subjects was similar ( $48.9 \pm 28.3 \%$ vs. $46.9 \pm 29.9 \%, p=0.8$ ). After 7 days of clopidogrel treatment no significant difference in the extent of aggregation was detected between the study groups $(58.7 \pm 21.3 \%$ vs. $66.0 \pm 17.7 \%, p=0.2)$. According to the binary definition $14 \%$ of patients were resistant to ASA in the ST group and $29 \%$ of patients in the control group $(p=0.7)$. Also there was no difference in the incidence of clopidogrel resistance ( $57 \%$ vs. $48 \%, p=0.4$ respectively). In 13 patients resistant to clopidogrel a dual maintenance dose (150 $\mathrm{mg}$ daily) resulted in significant reduction of maximal ADP-induced aggregation after 7 days $(73.6 \pm 16.7 \%$ vs. $60.2 \pm 11.3 \%$, $p=0.037)$

Conclusions: Clinical and angiographic variables other than laboratory identified platelet resistance to ASA and clopidogrel may play a more important role in the development of subacute stent thrombosis in patients treated with PCI for ACS. Doubling the maintenance dose of clopidogrel may reduce the incidence of platelet resistance.
\end{abstract}

Key words: stent thrombosis, platelet resistance to ASA and clopidogrel

Streszczenie

Wstęp: Zakrzepica w stencie (ZS) stanowi jedno z najcięższych powikłań kardiologii interwencyjnej.

Cel: Ocena związku pomiędzy odpowiedzią płytek krwi na kwas acetylosalicylowy (ASA) i klopidogrel a wystąpieniem podostrej ZS u chorych z wywiadem ostrego zespołu wieńcowego (OZW) oraz sprawdzenie wpływu podwojenia dawki podtrzymującej klopidogrelu na odpowiedź płytek.

Corresponding author/Adres do korespondencji:

Jerzy Pręgowski MD, PhD, Klinika Kardiologii i Angiologii Interwencyjnej, Instytut Kardiologii, ul. Alpejska 42, 04-628 Warszawa,

tel.: +48 2281540 14, e-mail: jerzypregowski74@gmail.com

Praca wpłynęła 20.10.2010, wersja poprawiona 6.11.2010, przyjęta do druku 10.11.2010. 
Materiał i metody: W wyniku retrospektywnego przeszukania prospektywnego jednoośrodkowego Rejestru Zawałów Serca ANIN do badania włączono 22 chorych z wywiadem podostrej ZS oraz 36 pacjentów z wywiadem OZW niepowikłanego ZS. Funkcję płytek krwi oceniano metodą agregometrii optycznej po stymulacji epinefryną ( $30 \mu \mathrm{mol} / \mathrm{l})$ oraz ADP $(5 \mu \mathrm{mol} / \mathrm{l})$. Badania wykonywano podczas leczenia ASA (75 mg/dobę) w monoterapii oraz 7 dni po włączeniu leczenia klopidogrelem (75 mg/dobę). U pacjentów ze stwierdzoną opornością na klopidogrel ponownie oceniono funkcję płytek krwi po 7 dniach leczenia podwójną dawką klopidogrelu (150 mg/dobę).

Wyniki: Maksymalna agregacja indukowana epinefryną podczas monoterapii ASA była podobna w obu grupach (48,9 $\pm 28,3 \%$ vs 46,9 $\pm 29,9 \%, p=0,8$ ). Również maksymalna agregacja indukowana ADP obserwowana po 7 dniach od włączenia leczenia klopidogrelem była podobna w obu badanych grupach $(58,7 \pm 21,3 \%$ vs $66,0 \pm 17,7 \%, p=0,2)$. Częstość oporności na ASA i klopidogrel była podobna w grupie chorych z wywiadem ZS i w grupie kontrolnej (odpowiednio 14\% vs 29\%, $p=0,7$ oraz 57\% vs 48\%, $p=0,4$ ). U 13 pacjentów z opornością na klopidogrel podanie podwójnej dawki prowadziło do zmniejszenia agregacji płytek indukowanej ADP $(73,6 \pm 16,7 \%$ vs $60,2 \pm 11,3 \%, p=0,037)$.

Wnioski: Cechy kliniczne i angiograficzne inne niż oceniana laboratoryjnie oporność płytek krwi na leczenie ASA i klopidogrelem, mogą odgrywać ważną rolę w powstawaniu podostrej zakrzepicy w stencie u pacjentów leczonych PCI z powodu OZW. Stosowanie podwójnej dawki podtrzymującej klopidogrelu może zmniejszyć częstość występowania oporności płytek.

Słowa kluczowe: zakrzepica w stencie, oporność płytek krwi na ASA i klopidogrel

\section{Introduction}

Stent thrombosis although rare is a catastrophic complication of percutaneous coronary interventions (PCI) with mortality up to $40 \%$ [1-6]. It is believed that acute stent thrombosis that occurs within $24 \mathrm{~h}$ from stent implantation is mostly related to procedural factors, i.e. stent malapposition or underexpansion [7]. If stent thrombosis occurs subacutely (> $24 \mathrm{~h}-1$ month) other factors may also play a pivotal role. It has been shown that an inadequate response to a dual antiplatelet regime may increase the risk of cardiovascular ischaemic complications including stent thrombosis in the general population of patients undergoing coronary stenting [8-15]. However, there is no study addressing the issue of angiographically documented stent thrombosis solely in the population of patients after $\mathrm{PCl}$ performed for acute coronary syndrome. Therefore, the aim of our study was to assess the relation between subacute stent thrombosis and response to antiplatelet treatment in patients with acute coronary syndrome and to check the effect of doubling the maintenance dose of clopidogrel on platelet response.

\section{Material and methods}

The study was a single centre retrospective case controlled analysis. The protocol was approved by the local ethics committee and all subjects gave written informed consent. The patients with subacute stent thrombosis were identified retrospectively from our prospective ANIN Myocardial Infarction Registry by a review of the logs containing information on all the patients admitted to the high-volume catheterization laboratory. First, the names of the patients admitted with acute coronary syndromes were found and then the logs were searched to check if the same patient was admitted to the catheterization laboratory again within the month following the baseline procedure. This allowed us to identify a cohort of consecutive patients who developed angiographically documented subacute stent thrombosis following successful PCl with stent implantation into a de-novo lesion in the setting of acute coronary syndrome (both with ST segment elevation (STEMI) and without ST segment elevation (NSTE ACS). Then all identified stent thrombosis survivors were contacted, assessed for eligibility and invited to participate in the study. Successful baseline intervention was defined as lack of angiographic evidence of residual stenosis (< $20 \%$ lumen diameter stenosis on visual assessment) and restoration of TIMI 3 flow in the infarct related artery as assessed by the operator at the end of the procedure. Patients with NSTE ACS had to be troponin positive (troponin I, cut point value $\geq 0.1 \mathrm{ng} / \mathrm{ml}$ ) to be eligible for the study. Serving as a control group were patients who underwent $\mathrm{PCl}$ with stent implantation for acute coronary syndrome uncomplicated by subacute stent thrombosis. Control patients were matched with regard to age, gender and clinical presentation (STEMI vs. NSTE ACS) but not for angiographic and procedural variables. The large database of consecutive patients admitted with acute coronary syndrome (ANIN Myocardial Infarction Registry) was used for the computer-assisted matching process. The exclusion criteria were the same for both study and control group and included chronic treatment with thienopyridines, acenocoumarol or non-steroid anti-inflammatory drugs, known allergy to acetylsalicylic acid (ASA) or clopidogrel, recent gastro-intestinal bleeding (within the preceding 12 months), low platelet count (below $100000 / \mu \mathrm{l}$ ), bleeding disorder or high risk of bleeding. All patients enrolled (from the study group and controls) were on chronic ASA treatment at the dose of $75 \mathrm{mg}$ daily and were not taking other antiplatelet medication. At the first visit baseline platelet aggregation tests were performed in both study groups. Then all patients started clopidogrel treatment (loading dose of $300 \mathrm{mg}$ ) and platelet aggregation was measured after $4 \mathrm{~h}$. The next platelet aggregation assessment was performed after 7 days of clopidogrel treatment (75 mg daily). Patients in whom clopidogrel resistance was identified (from both the stent thrombosis and the control group) were administered a maintenance 
dose of $150 \mathrm{mg}$ (75 mg twice daily) and after 7 days platelet aggregation was assessed again.

\section{Platelet function assessment with light transmittance aggregometry}

Citrated venous blood collected in tubes containing $3.8 \%$ buffered trisodium citrate was used for all measurements. Blood samples were processed within $1 \mathrm{~h}$ of collection. Turbidimetric platelet aggregation was performed in platelet-rich plasma with platelet count adjusted to $250 \times 10^{3} / \mathrm{mm}^{3}$ in the aggregometer Chronolog 707. Platelet-rich plasma was stimulated with agonists to determine the response to treatment. The extent of aggregation was defined as the maximal light transmission after addition of the agonist, with platelet-poor plasma used as a reference. Stimulation with $5 \mu \mathrm{mol}$ of adenosine 5'-diphosphate (ADP) at appropriate time intervals was performed to determine the response to clopidogrel treatment. Normal response to clopidogrel was defined as inhibition of the maximal aggregation under ASA plus clopidogrel $\geq 10 \%$ as measured in relation to baseline ADPinduced aggregation (before the loading dose of clopidogrel). If the inhibition of aggregation was less than $10 \%$, these patients were defined as resistant to clopidogrel [8]. High post-treatment platelet reactivity was defined as maximal platelet aggregation $>60 \%$ after 7 days of

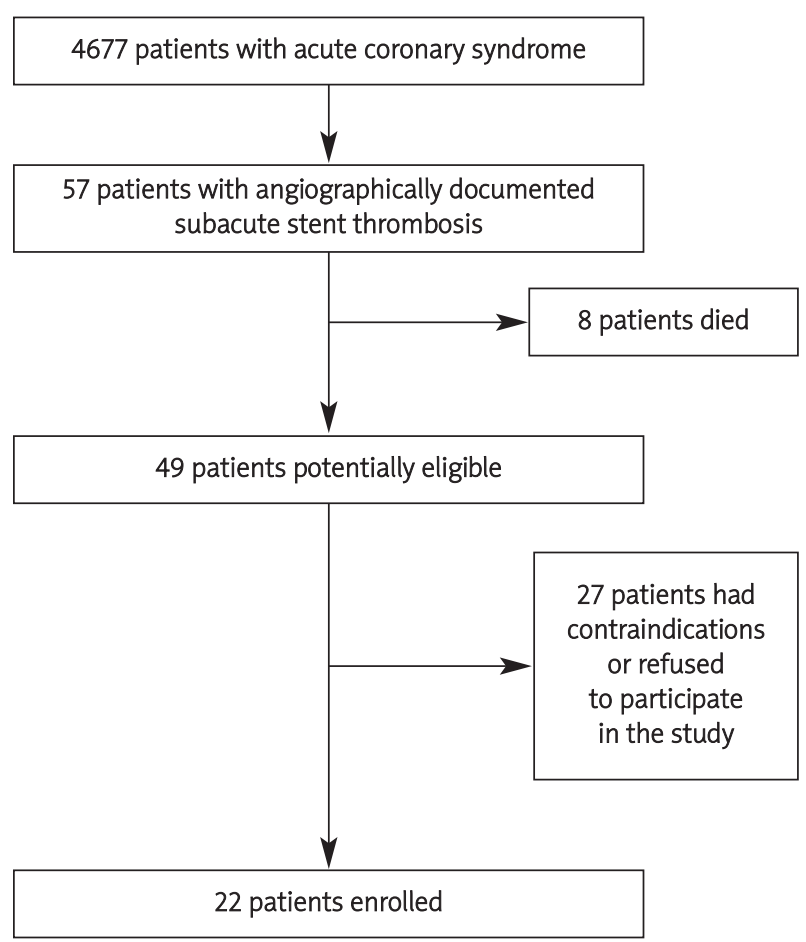

Fig. 1. Patients' flow chart (subacute stent thrombosis group)

Ryc. 1. Schemat obrazujący sposób wyodrębnienia badanej grupy pacjentów z udokumentowana angiograficznie podostra zakrzepica w stencie clopidogrel treatment. Aggregation stimulated by epinephrine $(30 \mu \mathrm{mol})$ was performed at baseline before the loading dose of clopidogrel to assess ASA responsiveness. To assess platelet responsiveness in an ASA-naive population the epinephrine-induced aggregation was assessed in a group of 15 healthy volunteers. Acetylsalicylic acid resistance in the stent thrombosis group and control group was defined as inhibition of the extent aggregation by epinephrine $<10 \%$ as compared to the healthy volunteers.

\section{Platelet function assessment with PFA-100} analyser

The PFA-100 device (Dade-Behring, Düdingen, Switzerland) assesses the blood flow in disposable test cartridges. The cartridges consist of a capillary and a membrane coated with type I collagen and either epinephrine (EPI cartridge) or adenosine 5'-diphosphate (ADP cartridge). Blood is pipetted into the reservoir and aspirated through a capillary. The capillary ends in a membrane aperture. Platelets adhere at the aperture where they are activated by the collagen and then aggregate. The epinephrine and ADP enhance aggregation. When a platelet plug forms the aperture closes and blood flow stops. The time from the beginning of the test until aperture occlusion is called closure time (CT). The lower the time the higher the platelet reactivity. The tests with EPI and ADP cartridges were performed at baseline only to assess platelet reactivity during ASA treatment.

\section{Statistical analyses}

Continuous data were presented as mean \pm standard deviation or as median and interquartile range (IQR) and compared with two-sided t-test or Mann-Whitney test. Categorical data were compared with chi square test. SPSS version 16.0 (SPSS, Inc., Chicago, IL) was used.

\section{Results}

\section{Patient population}

Between February 2001 and February 2006 there were 4677 patients who underwent stent implantation for acute coronary syndrome in our centre. Angiographically documented subacute stent thrombosis was found in 57 patients. Of these 8 patients died in hospital. The remaining 49 patients were contacted and assessed for eligibility for the study. Twenty-seven patients had contraindications or refused to participate in the study. Thus, the study group comprised 22 patients with a history of angiographically documented subacute stent thrombosis (fig. 1). Twenty identified and eligible subacute stent thrombosis cases occurred during the hospitalization for baseline ACS. The control group consisted of 36 patients treated with stent implantation for acute coronary syndrome. Both the study group and control patients were 
similar regarding baseline clinical characteristics (tab. 1). However, patients who developed stent thrombosis had more stents implanted and the vessel segment covered with stent was longer. Median time between stent implantation for acute coronary syndrome and stent thrombosis was 4 (3-6) days in the study group. The time between index ACS event and platelet responsiveness assessment was $32 \pm 16$ months for the study group and $26 \pm 12$ months for control patients ( $p=$ NS).

\section{Acetylsalicylic acid responsiveness}

Mean epinephrine-induced platelet aggregation in a control group of 15 healthy SA-naive volunteers was 92.4\%. Aggregation in patients on ASA who developed stent thrombosis and in control subjects who were treated for ACS without subsequent complications was similar $(48.9 \% \pm 28.3 \%$ vs. $46.9 \% \pm 29.9 \%, p=0.8)$. According to the binary definition based on optical aggregometry there were 3 patients (14\%) resistant to ASA in the study group and 9 patients (25\%) in the control group ( $p=N S)$. In the test with PFA-100 mean closure time for EPI cartridges was $187.2 \pm 81.0 \mathrm{~s}$ for patients with stent thrombosis and $213 \pm 80.7 \mathrm{~s}$ for control patients $(p=0.3)$. Also we did not observe a significant difference in the test using ADP cartridges (73.9 s vs. $78.4 \mathrm{~s}, p=0.3$, respectively).

\section{Clopidogrel responsiveness}

Clopidogrel responsiveness at baseline and $4 \mathrm{~h}$ after loading dose was assessed in all patients enrolled. The assessment after 7 days was repeated in 21 patients from the stent thrombosis group (1 patient did not arrive for the scheduled examination) and in 31 patients from the control group ( 5 patients did not arrive for the scheduled examination).

Baseline maximal ADP-induced platelet aggregation tended to be smaller in patients with stent thrombosis (72.3\% $\pm 17.6 \%$ vs. $80.1 \% \pm 11.9 \%, p=0.053)$. Clopidogrel significantly reduced maximal aggregation in the whole population (stent thrombosis group and control patients together) $4 \mathrm{~h}$ after the loading dose and after 7 days of treatment with a daily dose of $75 \mathrm{mg}$ (fig. 2). Four hours after the loading dose aggregation curves were similar in both study groups (maximal aggregation: $51.4 \pm 16.1 \%$ vs. $58.4 \pm 14.8 \%, p=0.097$ ). Also after 7 days of treatment with $75 \mathrm{mg}$ of clopidogrel no significant difference in the extent of aggregation was detected $(58.7 \pm 21.3 \%$ vs. $66.0 \pm 17.7 \%, p=0.2$ ). According to the binary definitions $4 \mathrm{~h}$ after the loading dose there were numerically more clopidogrel-resistant patients in the stent thrombosis group than among control subjects, but the difference was not significant $(40 \%$ vs. $25 \%$, $p=0.5$ ). At 7 days of treatment the respective numbers were $57 \%$ vs. $48 \%(p=0.4)$. The incidence of high posttreatment platelet reactivity after 7 days of taking a maintenance dose was $47 \%$ in the stent thrombosis group vs. $60 \%$ among control subjects $(p=0.4)$. Also the proportion of subjects with laboratory identified combined resistance to ASA and clopidogrel was similar in both study groups ( $6 \%$ vs. $9 \%, p=1.0)$

Table 1. Baseline demographic and angiographic characteristics

Tabela 1. Wyjściowa charakterystyka demograficzna i angiograficzna

\begin{tabular}{|c|c|c|c|}
\hline & Stent thrombosis group $(n=22)$ & Control group $(n=36)$ & $p$ \\
\hline Age [years, mean \pm SD] & $58.9 \pm 10.3$ & $56.4 \pm 8.0$ & 0.3 \\
\hline Male [\%] & 77 & 84 & 0.7 \\
\hline STEMI [\%] & 64 & 73 & 0.5 \\
\hline Diabetes mellitus [\%] & 23 & 16 & 0.7 \\
\hline Hypertension [\%] & 81 & 69 & 0.4 \\
\hline Current smoking [\%] & 45 & 38 & 0.6 \\
\hline Dyslipidaemia [\%] & 86 & 86 & 1.0 \\
\hline Previous myocardial infarction [\%] & 27 & 16 & 0.2 \\
\hline Atorvastatin treatment [\%] & 64 & 43 & 0.2 \\
\hline \multicolumn{4}{|l|}{ Angiographic variables } \\
\hline Number of stents & $1.4 \pm 0.6$ & $1.1 \pm 0.2$ & 0.07 \\
\hline Length of stented segment [mm] & $25.3 \pm 12.4$ & $16.9 \pm 5.8$ & 0.02 \\
\hline Stent diameter $[\mathrm{mm}]$ & $3.1 \pm 0.3$ & $3.1 \pm 0.4$ & 0.9 \\
\hline \multicolumn{4}{|l|}{ Culprit vessel } \\
\hline LAD [\%] & 68 & 48 & 0.3 \\
\hline LCX [\%] & 18 & 27 & \\
\hline RCA [\%] & 14 & 25 & \\
\hline
\end{tabular}




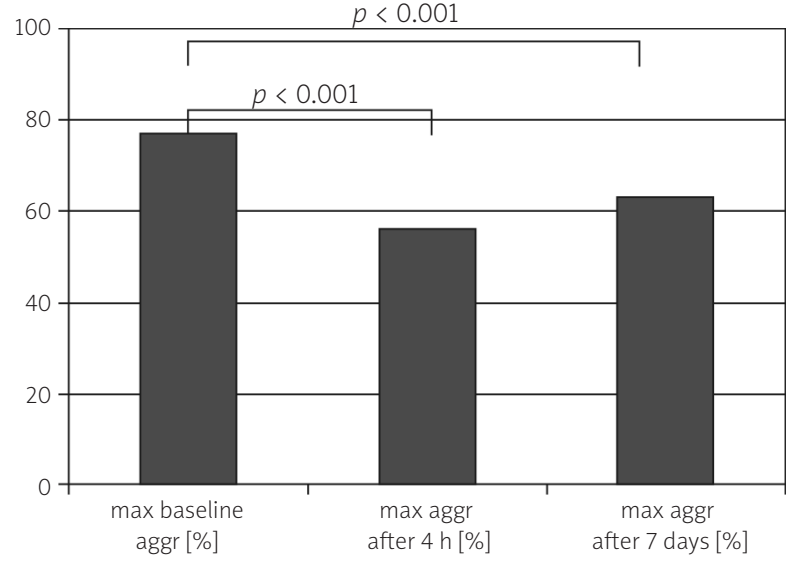

Fig. 2. Maximal ADP-induced aggregation for the whole group (stent thrombosis and control patients) at baseline, $4 \mathrm{~h}$ after $300 \mathrm{mg}$ of clopidogrel and after 7 days of treatment with daily dose of $75 \mathrm{mg}$ of clopidogrel

Ryc. 2. Maksymalna agregacja indukowana ADP $w$ catej badanej grupie (chorych $z$ wywiadem zakrzepicy w stencie i pacjentów z grupy kontrolnej) przed podaniem klopidogrelu, po 4 godz. od podania dawki $300 \mathrm{mg}$ oraz po 7 dniach leczenia dawką $75 \mathrm{mg} /$ dobę

Effect of double maintenance dose of clopidogrel on platelet responsiveness

There were 13 patients out of 27 found resistant to clopidogrel (as assessed after 7 days of treatment) who agreed to take a double maintenance dose of the drug (150 mg daily) for another 7 days. Mean ADP-induced aggregation decreased from $73.6 \% \pm 16.7 \%$ (after 7 days of $75 \mathrm{mg}$ ) to $60.2 \% \pm 11.3 \%$ (after 7 days of $150 \mathrm{mg}$ ) $(p=0.037)$. In 6 patients the maximal ADP-induced platelet aggregation decreased by more than $40 \%$, in 6 patients it remained unchanged and in one case stronger aggregation after a double dose was observed. An example of aggregation curves at baseline, after 7 days of $75 \mathrm{mg}$ and after 7 days of $150 \mathrm{mg}$ of clopidogrel is presented in figure 3.

\section{Discussion}

The main findings of the current study are as follows: 1) platelet resistance to ASA and clopidogrel was identified in a similar proportion of patients with subacute stent thrombosis and control subjects; 2) laboratory identified platelet resistance to clopidogrel in around $50 \%$ of patients was overcome by the double maintenance dose of the drug.

The results regarding the relation between clopidogrel responsiveness and occurrence of stent thrombosis obtained in our study are similar to those presented in a retrospective study of similar design by Wenaweser et al. [8]. However, Wenaweser et al. found that patients who

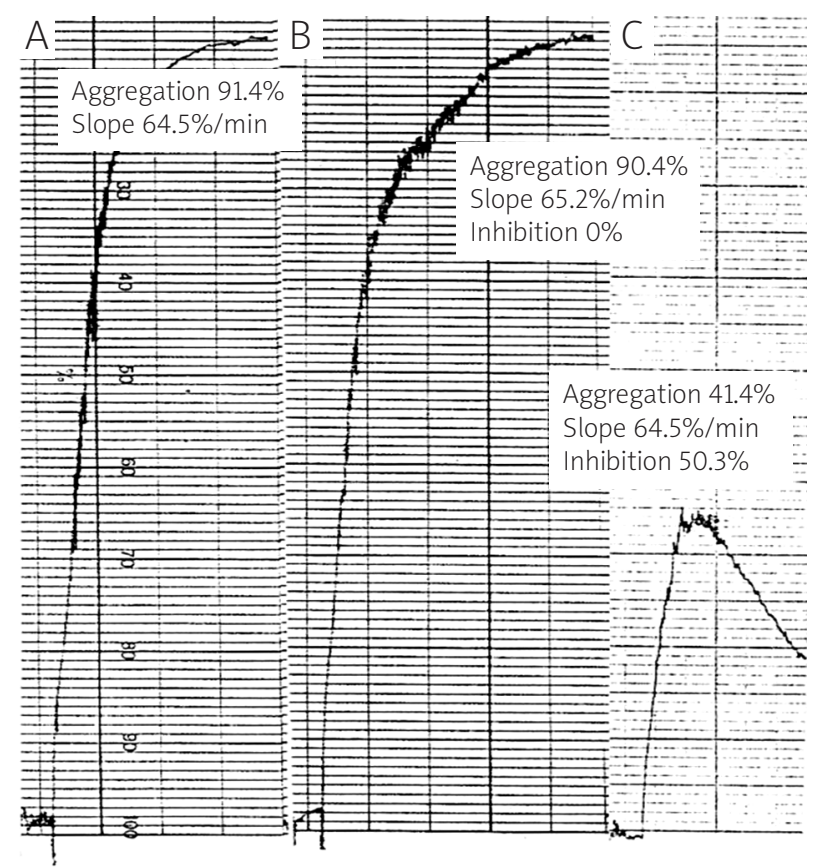

A - baseline aggregation, B - after 7 days of $75 \mathrm{mg}, \mathrm{C}$ - after 7 days of $150 \mathrm{mg}$

Fig. 3. Platelet aggregation after ADP in the patient resistant to typical daily dose of $75 \mathrm{mg}$ clopidogrel Ryc. 3. Agregacja ptytek krwi indukowana ADP u pacjenta opornego na leczenie typowa dawka (75 mg/dobę) klopidogrelu

developed stent thrombosis (23 subjects) were more often resistant to ASA, which was not observed in the current paper. A possible explanation of this discrepancy is that Wenaweser et al. used arachidonic acid as the platelet agonist to assess ASA responsiveness while in our study epinephrine-induced aggregation was performed. Another issue is that the paper by Wenaweser et al. was based on a mixed patient population (both stable and unstable patients) while the current study was performed exclusively on subjects with acute coronary syndrome. Moreover, the proportion of stable and unstable subjects in study and control groups in the study by Wenaweser et al. was significantly different ( $83 \%$ vs. $43 \%$ ). Another retrospective case control study based on a mixed population was reported by Gurbel et al., who found that platelet response to ASA (assessed by arachidonic acid induced aggregation) was not related to the occurrence of subacute stent thrombosis - which is similar to our results and contrary to the report by Wenaweser et al. [9]. Gurbel et al. also identified high post-clopidogrel-treatment platelet reactivity to ADP as a risk factor of stent thrombosis, which is in contrast with the current report and again in contrast with the paper by Wenaweser et al. Recently Buonamici et al. published a prospective observational study involving 804 consecutive patients who underwent drug-eluting stent implantation and found that clopidogrel resistance was an independent predictor of definite or probable stent thrombosis [10]. However, it should be noted that the 
population studied by Buonamici et al. included a substantial proportion of subjects with stable angina and moreover all patients received drug-eluting stents while all the patients from our group were treated with bare metal stent implantation. It seems possible that the type of the stent implanted (DES vs. BMS) may influence the relation between clopidogrel responsiveness and stent thrombosis. The definition of stent thrombosis was different in the two studies. We included only patients with angiographically documented stent thrombosis, while Buonamici et al. classified as probable stent thrombosis also unexplained death or myocardial infarction in the territory supplied by a stented vessel without angiographic confirmation. Interestingly, the incidence of stent thrombosis in the study by Buonamici et al. was 3.1\%, which is twice as high as in other reports. The authors partially attribute the observed incidence of stent thrombosis to the high complexity of lesions that were stented. The finding indicating that procedural factors, especially the length of the stented segments, are related to the occurrence of stent thrombosis are in line with previous reports and most likely does not need special comments [1-7, 16, 17]. However, it should be stressed that "traditional risk factors" related to stent thrombosis seem better documented than platelet resistance to ASA or clopidogrel. The results of our study showing lack of a relation between platelet responsiveness to clopidogrel/ASA and stent thrombosis are in contrast to the results of numerous publications showing that an inadequate response to antiplatelet therapy is associated with worse clinical outcomes [8-15]. Among those papers is also a single-centre prospective study showing a relationship between clopidogrel resistance and clinical outcome (cardiovascular death and non-fatal MI) following PCI for ACS [18]. However, the potential strength of our study is that we enrolled only subjects with angiographically documented subacute stent thrombosis.

Our results indicating that a higher maintenance dose may be an effective approach to lower post-treatment platelet activity are in line with the report by von Beckerath et al., who found that patients treated with $150 \mathrm{mg}$ of clopidogrel daily have lower maximal ADP-induced platelet aggregation [19]. In the study mentioned above, 60 nonselected patients were randomized to receive either $75 \mathrm{mg}$ or $150 \mathrm{mg}$ of clopidogrel. Also, Angiolillo et al. reported increased platelet inhibition during treatment with a double maintenance dose of clopidogrel [15]. The current paper differs from the paper by Beckerath et al. and Angiolillo et al. in that the patients who received a double dose were selected on the basis of impaired initial response to the dose of $75 \mathrm{mg}$.

\section{Study limitations}

The current study is retrospective and involves a relatively small number of patients with low statistical power to detect possible differences in platelet responsiveness between the two groups. We did not perform intravascular ultrasound at the time of stent thrombosis to assess procedural effects (stent expansion, apposition, stent edge dissections) that are associated with stent thrombosis. A potential bias might have occurred due to the high mortality of patients with stent thrombosis and high number of patients who had either contraindications or refused to participate in the study. Moreover, it is likely that there were some patients who developed stent thrombosis after discharge from our hospital and were treated in a different centre. It is possible that platelet responsiveness to ASA and clopidogrel may differ within the first month following acute coronary syndrome and in the longer follow-up. However, it is likely that genetic polymorphism is a key factor associated with variability in responce to the antiplatelet drugs [20-23]. Only $60 \%$ of patients with identified laboratory resistance to clopidogrel agreed to take a double maintenance dose of the drug.

\section{Conclusions}

Clinical and angiographic variables other than laboratory identified platelet resistance to ASA and clopidogrel may play more important role in the development of subacute stent thrombosis in patients treated with $\mathrm{PCl}$ for acute coronary syndrome. Doubling the maintenance dose of clopidogrel may reduce the incidence of platelet resistance.

\section{References}

1. Cutlip DE, Baim DS, Ho KK, et al. Stent thrombosis in the modern era a pooled analysis of multicenter coronary stent clinical trials. Circulation 2001; 103: 1967-1971.

2. Orford JL, Lennon R, Melby S, et al. Frequency and correlates of coronary stent thrombosis in the modern era analysis of a single center registry. J Am Coll Cardiol 2002; 40: 1567-1572.

3. lakovou I, Schmidt T, Bonizzoni E, et al. Incidence, predictors, and outcome of thrombosis after successful implantation of drugeluting stents. JAMA 2005; 293: 2126-2130.

4. Moussa I, Di Mario C, Reimers B, et al. Subacute stent thrombosis in the era of intravascular ultrasound-guided coronary stenting without anticoagulation: frequency, predictors and clinical outcome. J Am Coll Cardiol 1997; 29: 6-12.

5. Uren NG, Schwarzacher SP, Metz JA, et al. Predictors and outcomes of stent thrombosis: an intravascular ultrasound registry. Eur Heart J 2002; 23: 124-132.

6. Wenaweser P, Rey C, Eberli F, et al. Stent thrombosis following bare-metal stent implantation: success of emergency percutaneous coronary intervention and predictors of adverse outcome. Eur Heart J 2005; 26: 1180-1187.

7. Heestermans AA, Van Werkum JW, Zwart B et al. Acute and subacute stent thrombosis after primary PCI for ST-segment elevation myocardial infarction: incidence, predictors and clinical outcome. J Thromb Haemost 2010 Sep 10. doi: 10.1111/j.15387836.2010.04046.x 
8. Wenaweser P, Dörffler-Melly J, Imboden K, et al. Stent thrombosis is associated with an impaired response to antiplatelet therapy. J Am Coll Cardiol 2005; 45: 1748-1752.

9. Gurbel PA, Bliden KP, Samara W, et al. Clopidogrel effect on platelet reactivity in patients with stent thrombosis. Results of the CREST Study. J Am Coll Cardiol 2005; 46: 1827-1832.

10. Buonamici P, Marcucci R, Migliorini A, et al. Impact of platelet reactivity after clopidogrel administration on drug-eluting stent thrombosis. J Am Coll Cardiol 2007; 49: 2312-2317.

11. Matetzky S, Shenkman B, Guetta V, et al. Clopidogrel resistance is associated with increased risk of recurrent atherothrombotic events in patients with acute myocardial infarction. Circulation 2004; 109 : 3171-3175.

12. Price MJ, Endemann S, Gollapudi RR, et al. Prognostic significance of post-clopidogrel platelet reactivity assessed by a point-of-care assay on thrombotic events after drug-eluting stent implantation. Eur Heart J 2008; 29: 992-1000.

13. Hochholzer W, Trenk D, Bestehorn HP, et al. Impact of the degree of peri-interventional platelet inhibition after loading placement with clopidogrel on early clinical outcome of elective coronary stent. J Am Coll Cardiol 2006; 48: 1742-1750.

14. Gori AM, Marcucci R, Migliorini A, et al. Incidence and clinical Impact of dual nonresponsiveness to aspirin and clopidogrel in patients with drug eluting stents. J Am Coll Cardiol 2008; 52: 734-739.

15. Angiolillo DJ, Bernardo E, Palazuelos J, et al. Functional impact of high clpidogrel maintenance dosing in patients undergoing elective percutaneous coronary interventions. Results of a randomized study. Thromb Haemost 2008; 99: 161-168.
16. Alfonso F, Suárez A, Angiolillo DJ, et al. Findings of intravascular ultrasound during acute stent thrombosis. Heart 2004; 90: 1455-1459.

17. Cheneau E, Leborgne L, Mintz GS, et al. Predictors of subacute stent thrombosis: results of a systematic intravascular ultrasound study. Circulation 2003; 108: 43-47.

18. Marcucci R, Gori AM, Paniccia R, et al. Cardiovascular death and nonfatal myocardial infarction in acute coronary syndrome patients receiving coronary stenting are predicted by residual platelet reactivity to ADP detected by a point-of-care assay A 12-month follow-up. Circulation 2009; 119: 237-242.

19. Von Beckerath N, Kastrati A, Wieczorek A, et al. A double-blind, randomized study on platelet aggregation in patients treated with a daily dose of 150 or $75 \mathrm{mg}$ of clopidogrel for 30 days. Eur Heart J 2007; 28: 1814-1819.

20. Eikelboom JW, Hirsh J, Weitz JI, et al. Aspirin resistant thromboxane biosynthesis and the risk of myocardial infarction, stroke, or cardiovascular death in patients at high risk for cardiovascular events. Circulation 2002; 105: 1650-1655.

21. Mega JL, Close SL, Wiviott SD, et al. Cytochrome p-450 polymorphisms and response to clopidogrel. N Engl J Med 2009; 360: 354-362.

22. Halushka MK, Halushka PV. Why are some individuals resistant to the cardioprotective effects of aspirin? Could it be thromboxane A2? Circulation 2002; 105: 1620-1622.

23. O'Donnell CJ, Larson MG, Feng D, et al. Genetic and environmental contributions to platelet aggregation: the Framingham heart study. Circulation 2001; 103: 3051-3056. 